\title{
Perancangan Fotografi Fashion Pewarna Alami dari Ampas Kopi
}

\author{
Mario Bonaventura Sunyoto ${ }^{1^{*}}$, Baskoro Suryo Banindro ${ }^{2}$, Yusuf Hendra Yulianto ${ }^{3}$ \\ 1,3 Program Studi Desain Komunikasi Visual, Fakultas Seni dan Desain, \\ Universitas Kristen Petra, Jl. Siwalankerto 121-131, Surabaya \\ 2 Program Studi Desain Komunikasi Visual, Fakultas Seni Rupa, \\ Institut Seni Indonesia Yogyakarta, Jl. Parangtritis Km. 6.5, Yogyakarta \\ *Penulis korespondensi; E-mail: kaeeell27@gmail.com
}

\begin{abstract}
Abstrak
Seiring dengan perkembangan zaman, kebutuhan manusia semakin beragam. Berkumpul bersama untuk sekedar meminum kopi menjadi sebuah kebiasaan baru yang harus dilakukan. Pakaian juga bukan lagi hanya sebagai kebutuhan tetapi menjadi gaya hidup. Sejalan dengan berkembangya bisnis kedai kopi dan industri fashion di Indonesia limbah kopi dan pewarna tekstil yang tinggi dihasilkan. Masalah limbah ini dapat diselesaikan dengan penggunaan pewarna alami dari ampas kopi. Dengan menggunakan analisis data $5 \mathrm{~W} 1 \mathrm{H}$, perancangan ini bertujuan untuk membuat masyarakat tertarik dengan produk fashion yang menggunakan pewarna alami melalui fotografi fashion.
\end{abstract}

Kata kunci: Fotografi, Fashion, Kopi, Indonesia, Pewarna, Alami.

\begin{abstract}
As time goes, human needs are increasingly diversified. To gather together only to drink coffee is a new must habit. Clothing is also no longer just a necessity; it becomes a lifestyle. As the coffee shop business and fashion industry develop, high levels of coffee waste and textile dyes pollution are produced. This waste problem can be solved by using natural dyes made from coffee grounds. By using $5 \mathrm{~W} 1 \mathrm{H}$, this design aims to catch people's interest in naturally dyed fashion products through fashion photography.
\end{abstract}

Keywords: Photography, Fashion, Coffee, Indonesia, Dye, Natural.

\section{Pendahuluan}

Pakaian merupakan kebutuhan utama kita selain pangan dan papan (rumah). Manusia membutuhkan pakaian untuk menutupi dan melindungi diri. Namun seiring dengan perkembangan zaman, pakaian juga digunakan sebagai jabatan, kedudukan ataupun simbol status seseorang yang menggunakannya. Industri fashion telah menjadi industri besar dan mulai mencatat pertumbuhan output tertinggi di antara industri lain pada kuartal pertama 2019. Menurut data dari Biro Pusat Statistik, dalam tiga bulan pertama tahun ini, output industri fashion meningkat sebesar $29,19 \%$ setiap tahun. Pada saat yang sama, secara triwulanan, industri ini tumbuh sebesar $8,79 \%$, kedua setelah industri furnitur. Zat pewarna tekstil yang lebih sering dipakai saat ini oleh perusahaan-perusahaan kain yaitu pewarna sintetis. Karena selain faktor harganya yang murah, warna yang dihasilkan juga lebih cerah, tahan lama, proses pewarnaannya lebih cepat serta pilihan warnanya bermacam-macam. Pewarna sintetis menghasilkan limbah cair anorganik yang tidak dapat terurai. Banyak cara dilakukan untuk mengurangi limbah pewarna tekstil. Salah satu cara pengurangan limbah cair berupa pewarna tekstil adalah dengan kembali menggunakan bahan-bahan dari alam sebagai pewarna tekstil dan membuat motif pada tekstil. Dengan menggunakan natural dye atau pewarnaan alami dari ampas kopi yang diekstraksi serta bahan cairan pembantu lainnya yang tidak mengandung bahan kimia dapat menggantikan pewarna tekstil pewarnaan ini aman bagi lingkungan dan tidak mencemari air.

Pemilihan ampas kopi ini dikarenakan masyarakat Indonesia yang gemar mengonsumsi kopi dan kemunculan kedai kopi yang begitu banyak. Indonesia adalah negara yang 
mengkonsumsi kopi dengan jumlah terbesar di dunia. Konsumsi kopi Indonesia periode 2016/2017 mencapai 4,6 juta kemasan, setara dengan 60 kilogram dari data yang didapat International Coffee Organization (ICO). Dibawah Rusia, konsumsi kopi Indonesia menempati urutan keenam secara global. Meskipun konsumen kopi terbesar di dunia adalah negara yang bergabung dengan Uni Eropa, konsumsi kopinya melebihi 42,6 juta pound atau 60 kilogram. Dengan banyaknya konsumsi kopi akan menghasilkan limbah organik yaitu ampas kopi. Limbah organik ini tidak berbahaya bagi lingkungan dan mudah diurai. Banyaknya limbah dari trend budaya minum kopi ini dapat dimanfaatkan sebagai alternatif bahan pewarna pakaian yang ramah lingkungan.

Penting bagi pelaku industri fashion untuk mengenalkan kepada masyarakat bahwa ada produk fashion berbahan pewarna alami. Dengan demikian masyarakat dapat ikut serta melestarikan lingkungan secara tidak langsung. Selain itu produk fashion dari pewarna alami tidak kalah bagus dengan produk fashion konvensional. Salah satu solusinya, di Surabaya ada start up yang memproduksi fashion yang menggunakan pewarna alami di Surabaya, yaitu Kelana. Tidak hanya Kelana, ada beberapa merek lokal yang menggunakan pewarna alami produknya. Di Jakarta Osem merupakan salah satu pelopor label fashion ramah lingkungan di Indonesia yang berdiri sejak 2014. Label ini memproduksi pakaian dan aksesoris dengan mengandalkan bahan dari kain berserat alami seperti katun, linen, dan rami, serta hanya menggunakan pewarna alami berwarna indigo yang didapat dari tumbuhan Indigofera Tinctoria.

Untuk meramaikan market fashion di Surabaya, maka melalui perancangan tugas akhir ini akan ditawarkan kepada publik mengenai pewarnaan alami ampas kopi yang dapat menjadi alternatif pewarna fashion melalui fotografi fashion. Hal ini dilakukan karena pada era modern saat ini pertumbuhan fashion di Indonesia bertumbuh sangat pesat. NapoleonCat, sebuah perusahaan yang menganalisis data sosial media, mencatat bahwa pengguna media sosial Instagram di Indonesia pada November 2019 mencapai angka 61.610 .000 juta. Dari data tersebut, mayoritas pengguna adalah wanita dengan total $50,8 \%$ dan untuk pengguna laki-laki mencapai total $49,2 \%$. Selain jenis kelamin, perincian data user Instagram menggunakan data usia, dimulai dari 13-17 tahun, 18-24 tahun, 25-34 tahun, 35-44 tahun, 45-54 tahun, 55-64 tahun hingga 65 tahun atau lebih. Oleh karena itu, hasil perancangan ini akan disosialisasikan melalui salah satu sosial media instagram. Hal ini dilakukan karena menurut survei, pengguna sosial media instagram di Indonesia sangatlah besar. Dengan demikian, tujuan perancangan ini untuk mengenalkan fashion pewarna alami dari ampas kopi melalui fotografi fashion dapat tercapai melalui sosialisasi di Instagram.

Perancangan ini berbeda dengan dengan perancangan sebelumnya yang berjudul "Perancangan Promosi Kain Produk Kharisma dengan Pewarna Alami" karya Vanessa Wiratama, dimana perancangannya bertujuan sebagai kampanye komersial, dan produk fashionnya tidak menggunakan pewarna ampas kopi, melainkan pewarna alami daun mangga, kayu tinggi, tegeran, mahoni, keres, mengkudu, indigo, dan daun jati. Sedangkan perancangan saya bertujuan untuk memperkenalkan kepada masyarakat mengenai produk fashion pewarna alami salah satunya yang menggunakan ampas kopi.

\section{Metode Penelitian}

Metode pengumpulan data yang digunakan antara lain studi pustaka, yaitu pengumpulan sumber data yang diperoleh melalui media perantara atau secara tidak langsung yang berupa buku, catatan, bukti yang telah ada, atau arsip baik yang dipublikasikan maupun yang tidak dipublikasikan secara umum. Selain itu juga menggunakan wawancara tidak terstruktur. Pedoman wawancara yang digunakan hanya berupa garis-garis besar permasalahan yang akan ditanyakan. Setelah mendapatkan data yang diinginkan, selanjutnya data tersebut akan dianalisis dengan menggunakan analisis $5 \mathrm{~W}+1 \mathrm{H}$ yang terdiri dari apa (what), kenapa (why), siapa (who), dimana (where), kapan (when), dan bagaimana (how) untuk mendapatkan suatu konsep kreatif yang tepat dalam perancangan.

\section{Fotografi dan Ekspresi Seni}

Sudarma (2014:2) menjelaskan bahwa fotografi merupakan salah satu alat untuk berkomunikasi, yakni alat yang dapat dipergunakan untuk menyampaikan gagasan/pesan kepada orang. Fotografi merupakan sebuah media yang dapat digunakan untuk merekam suatu atau peristiwa penting atau momen. Menurut 
Bull (2010:5), fotografi berasalkan dari dua kata yunani: graphy dari graphe (tulisan atau gambar) dan photo dari phos (cahaya). Maka arti sesungguhnya fotografi adalah menggambar atau menulis menggunakan cahaya. Dengan ini fotografi dapat menjadi gabungan dari sebuah benda alami yaitu cahaya dengan kegiatan yang dilakukan oleh manusia yaitu menggambar dan menulis.

Sudjojo (2010) menjelaskan bahwa pada dasarnya, fotografi mengacu pada aktivitas merekam dan memanipulasi cahaya untuk mendapatkan hasil yang diinginkan. Fotografi dapat dibagi menjadi teknik dan seni. Gani dan Kusumalestari (2013: 4) mengutip Sudjojo (2010: vi) menyatakan bahwa untuk mengetahui cara memotret dengan benar, cara mengatur pen-cahayaan, dan cara memproses gambar. Fotografi sebagai karya seni mengandung nilai estetika dan mencerminkan konten dan perasaan kepala fotografer yang ingin me-nyampaikan informasi melalui foto/gambar. Fotografi tidak dapat didasarkan pada berbagai teori tentang cara mengambil gambar karena menghasilkan gambar yang sangat kaku, kurang menarik dan tidak berasa.

Sebagai media yang dapat merekam gambar, semua bentuk kehidupan dapat dihentikan dalam foto, seperti halnya menekan tombol "jeda" di bidang kehidupan, fotografi dapat menangkap dan menjadikannya abadi. Mengenai fotografi sebagai media, sebagai pembawa pesan, dan fotografi sebagai media pembantu di media. Gani dan Kusumalestari (2013: 6) menjelaskan pula bahwa di negara ini, sepertinya tidak ada media massa cetak (koran dan tabloid) yang tidak menggunakan foto. Sebelum membaca berita, foto biasanya menarik bagi pembaca. Posisi fotografi di sini adalah godaan, dan esensi dari jurnalisme foto adalah untuk mendukung atau menambah berita. Mereka menambahkan bahwa, secara umum, fotografi berita adalah gambar yang diciptakan melalui proses fotografi untuk membawa pesan, berita acara yang menarik bagi publik, dan untuk disebarluaskan melalui media massa.

Wijaya (2011: 10) menjelaskan, bahwa foto berita hanya foto yang layak berita atau foto yang menarik bagi pembaca tertentu, dan informasinya harus disebarluaskan kepada publik sebanyak mungkin. Fotografi sebagai media ekspresi terkait dengan fotografi sebagai media kreasi artistik. Calne (2004: 285) menyatakan bahwa seperti cinta, seni lebih mudah dijelajahi daripada memberikan definisi. Tidak mudah menemukan dua filsafat yang menyetujui definisi. Dapat dikatakan bahwa seni berkaitan dengan pertukaran ide dan selera melalui media sensual (warna, suara, perunggu, marmer, teks). Media ini diolah menjadi karya dengan karakteristik utama keindahan desain dan integritas bentuk. Karya ini memiliki fungsi untuk menarik pikiran, merangsang emosi, imajinasi dan meningkatkan indera.

Sumardjo (2000: 166) mengungkapkan, bahwa penciptaan karya seni adalah upaya untuk mengekspresikan diri dalam bentuk karya seni. Hauskeller (2015: 69) menjelaskan, bahwa Benjamin berpendapat fotografi dan film merupakan inovator di bidang seni, perkembangan dari bentuk seni lukis dan teater. Bull (2010: 141) percaya bahwa dari akhir abad ke-20 hingga awal abad ke-21, fotografi telah menjadi media yang banyak dipilih oleh para seniman. Bate (2009: 144) mengungkapkan bahwa ketika seseorang berbicara tentang dampak fotografi dalam seni, deskripsi umum tentang perubahan sosial dalam penciptaan gambar visual ini perlu dihafal dan konfirmasi. Dengan kata lain, perubahan artistik sejak zaman fotografi juga merupakan bagian dari perubahan besar dalam sejarah penggunaan dan penggunaan gambar oleh berbagai kelas masyarakat. Kita tidak bisa sepenuhnya membedakan pergeseran dalam praktik seni (dan teori) ini dari perubahan besar dalam media visual dalam budaya lain.

Untuk memahami karya potret secara lebih spesifik, ekspresi objek dalam foto adalah poin penting untuk menjelaskan karya potret. Suler (2013) berpendapat bahwa meskipun gambar tidak dapat menangkap gerakan tubuh, seperti yang ditunjukkan dalam video, gambar tersebut bagus untuk menggambarkan sifat orang yang diung-kapkan. Gambar dapat menangkap ekspresi tubuh yang dapat berlangsung hanya 1 detik, dan ekspresi ini dapat ditutupi oleh jumlah gerakan manusia.

\section{Fotografi Fashion}

Menurut Kamus Fotografi, fotografi fashion adalah cabang fotografi profesional yang berspesialisasi dalam foto-foto di bidang pakaian dan aksesori. Fotografer harus dapat menggabungkan pakaian dan model mereka menjadi satu gambar (foto yang harmonis). Dengan perkembangan media cetak yang lebih 
maju, bidang fotografi menjadi semakin luas. Fotografi fashion adalah jenis fotografi yang digunakan untuk mengekspos pakaian. Pada dasarnya, fotografi berfokus pada pakaian atau aksesoris yang dikenakan oleh model, dan fotografer juga cenderung menggunakan pencahayaan yang dramatis. Fotografi biasanya digunakan dalam editorial, iklan atau majalah mode, seperti Bazaar dan Vogue.

\section{Pewarna Alami}

Kata 'pewarna alami' mencakup semua pewarna yang berasal dari sumber alami seperti tumbuhan, hewan, dan mineral. Pewarna alami sebagian besar non-substantif dan harus diterapkan pada tekstil dengan bantuan mordan, biasanya garam logam, memiliki afinitas untuk zat pewarna dan serat. Ion logam transisi biasanya memiliki kekuatan koordinasi yang kuat dan/atau mampu membentuk gaya tarik/interaksi minggu ke medium dan dengan demikian dapat bertindak sebagai bahan penghubung untuk men-ciptakan substansi pewarna/pewarna alami ketika bahan tekstil diresapi dengan garam logam tersebut (yaitu Mordanted) dikenakan pewarnaan dengan pewarna alami yang berbeda, biasanya memiliki beberapa kelompok mordantable memfasilitasi fiksasi pewarna/pewarna tersebut. Mordan logam ini setelah dikombinasi dengan pewarna dalam serat, membentuk endapan atau danau yang tidak larut dan dengan demikian pewarna dan mordan diperbaiki untuk menjadi pencuci cepat ke tingkat yang wajar.

Keuntungan pewarna alami adalah:

1. Warna yang dihasilkan oleh pewarna alami/ pewarna biasanya lembut, berkilau dan menyejukkan mata manusia.

2. Zat warna alami dapat menghasilkan berbagai macam warna dengan sistem mix and match. Variasi kecil dalam teknik pewarnaan atau penggunaan mordan yang berbeda dengan pewarna yang sama (pewarna alami tipe poligenetik) dapat menggeser warna ke kisaran yang luas atau menciptakan warna yang benar-benar baru, yang tidak mudah dengan pewarna sintetis.

3. Zat warna alami menghasilkan ide warna langka dan secara otomatis selaras. Tidak seperti bahan baku dasar tidak terbarukan untuk pewarna sintetis, pewarna alami biasanya terbarukan, berbasis agroterbarukan atau berbasis sayuran dan pada saat yang sama dapat terurai secara hayati.
4. Dalam beberapa kasus seperti harda, nila dll., limbah dalam proses menjadi pupuk yang ideal untuk digunakan di bidang pertanian. Karena itu, tidak ada masalah pembuangan limbah alami ini.

5. Banyak tanaman yang tumbuh subur di tanah terlantar. Dengan demikian, pemanfaatan limbah merupakan nilai tambah dari pewarna alami. Pewarna seperti marah tumbuh sebagai inang di kebun teh. Jadi tidak ada biaya tambahan atau upaya yang diperlukan untuk menumbuhkannya. Ini adalah industri padat karya, dengan demikian memberikan peluang kerja bagi semua yang terlibat dalam budidaya, ekstraksi dan penerapan pewarna ini pada tekstil/makanan/kulit, dll.

6. Aplikasi pewarna alami memiliki potensi untuk mendapatkan kredit karbon dengan mengurangi konsumsi pewarna sintetis berbahan bakar fosil (minyak bumi).

7. Beberapa konstituennya adalah antialergen, karenanya terbukti aman untuk kontak kulit dan sebagian besar tidak berbahaya bagi kesehatan manusia.

8. Beberapa pewarna alami bertambah seiring bertambahnya usia, sementara pewarna sintetis memudar seiring waktu.

9. Pewarna alami berdarah tapi tidak menodai kain lain, kunyit menjadi pengecualian.

10.Pewarna alami biasanya merupakan bukti ngengat dan dapat menggantikan pewarna sintetis dalam pakaian anak-anak dan makanan untuk keamanan.

\section{Fashion}

Seperti yang ditulis oleh Kawamura (1991), pakaian merupakan konsep yang terpisah meskipun keduanya sering digunakan dan ditukar-tukar. Keduanya memiliki efek kemasyarakatan yang berbeda. Meskipun begitu, sebuah mode pakaian yang spesifik sering menjadi fokus dalam analisa. Kawamura mengutip tulisan Rouse (1989) bahwa sebuah model pakaian tertentu akan menjadi fashion, dimana model pakaian tersebut harus digunakan oleh beberapa orang serta diakui sebagai fashion. Dalam buku yang ditulis oleh Kawamura disebutkan bahwa memiliki keterkaitan yang sangat kecil dengan pakaian. Pakaian atau kostum merupakan benda material hasil produksi, sedangkan adalah simbol dari suatu hasil produksi. Pakaian adalah sesuatu yang nyata dan konkrit serta merupakan suatu kebutuhan, dan adalah sesuatu yang tidak nyata serta merupakan suatu tambahan yang tidak selalu dibutuhkan. 
Kawamura mengatakan fashion dapat diberlakukan sebagai objek hasil dari kebudayaan hasil organisasi sosial masyarakat. Objek hasil kebudayaan masyarakat sendiri dapat dianalisa dan dipelajari melalui perspektif konsumsi dan/atau produksinya, juga dapat menjadi topik analisa yang berkaitan dengan identitas dan hal-hal mengenai konsumsi pribadi, serta hal yang berkaitan dengan produksi dan distribusi yang merupakan simbol hasil kebudayaan tidak memiliki wujud dan tidak dapat dilihat oleh mata menggunakan pakaian sebagai simbol konkritnya.

Pakaian editorial dicampur oleh editor media. Proses ini termasuk editor, direktur seni, fotografer, penata busana, model, lemari pakaian, manajer lokasi, pencitraan digital, majalah Layouter dan banyak tim lain yang terlibat. Dalam desain ini, fokus desainer adalah pada konsep kreatif fotografer, ia bertindak sebagai aktor di belakang kamera, sehingga menciptakan papan kreatif, emosional dan memvisualisasikan konsep fotografi mode editorial. Fotografi dan mode adalah variabel terkait dan tidak terpisahkan, dimana fotografi merupakan media komunikasi penting dalam pengembangan mode. Fotografer dapat bertindak sebagai editor majalah untuk menguraikan proses penyuntingan dalam penelitian ini. Karena dalam proses belajar fotografi, karier fotografer yang sesungguhnya telah menjalin hubungan tim dengan banyak profesi. Fotografer adalah orang utama yang bertanggung jawab atas publikasi ini dan pada akhirnya bertanggung jawab untuk semua operasi dan kebijakan, dan memimpin semua pihak yang relevan.

\section{Analisis Data}

Perancangan ini menggunakan model analisis data $5 \mathrm{~W}+1 \mathrm{H}$ yang terdiri dari apa (what), kenapa (why), siapa (who), dimana (where), kapan (when), dan bagaimana (how). Hal yang diamati adalah:

\section{What}

1. Apa yang menyebabkan pewarna alami pada terutama yang menggunakan ampas kopi belum dikenal?

2. Masih sedikitnya pelaku bisnis fashion yang menggunakan pewarna alami ampas kopi dan masih sedikit upaya pengenalannya.

3. Apa pendapat masyarakat mengenai produk pewarna alami dari ampas kopi?
4. Bagi masyarakat produk pewarna alami dari ampas kopi tergolong cukup baru dan unik di bidang.

5. Media apakah yang digunakan selama ini untuk mengenalkan produk pewarna alami dari ampas kopi?

Why

1. Mengapa pewarna alami ampas kopi harus dimanfaatkan untuk produk fashion? Maraknya kedai kopi bermunculan dan tingginya konsumsi kopi di Indonesia membuat ampas kopi menjadi bahan pewarna alami yang ramah lingkungan dan jumlahnya yang banyak

2. Mengapa pewarna alami ampas kopi kurang dikenal oleh masyarakat?

Who

Siapa yang sudah memperkenalkan produk pewarna alami ampas kopi?

Where

1. Dimana pewarna alami ampas kopi yang sudah dikenalkan?

2. Dimana produk dengan pewarna alami ampas kopi ini di produksi?

How

1. Bagaimana cara pengenalan produk dengan limbah ampas kopi yang sudah dilakukan?

2. Bagaimana pengolahan ampas kopi oleh kedai kopi selama ini dilakukan?

Berangkat dari pertanyaan-pertanyaan di atas, dapat disimpulkan bahwa pakaian adat merupakan salah satu warisan budaya nasional yang harus dijaga dan dilestarikan. Namun, pakaian adat kurang mendapatkan perhatian dari remaja di Indonesia. Hal ini dikarenakan oleh visualisasi dari pakaian adat yang ada pada buku-buku pelajaran di sekolah kurang menarik yaitu terlihat kaku dan cenderung dengan pose frontal menghadap ke kamera. Sehingga, diperlukan adanya media edukasi untuk mengingatkan kembali remaja kepada pelajaran pakaian adat yang telah diajarkan di jenjang pendidikan sebelumnya melalui pendekatan fotografi mainan. Fotografi mainan dapat menjadi salah satu alternatif pemecahan masalah karena menyajikan hasil fotografi pakaian adat yang dekat dengan remaja dan luwes, di samping itu menerapkan aspek fotografi yang mengedepankan unsur pose dan ekspresi yang dinamis, santai, jenaka dan akrab. Melalui media fotografi mainan ini diharapkan dapat menjadi media yang menarik 
perhatian remaja terhadap pakaian adat Nusantara.

Tujuan dari perancangan ini adalah sebagai media pengenalan produk pewarna alami dari ampas kopi. Perancangan ini dilakukan agar produk pewarna alami dari ampas kopi mendapat perhatian lebih dari masyarakat. Produk fashion pewarna alami dari ampas kopi dapat dirancang dengan leluasa dan sekreatif mungkin untuk dapat tampil stylish dan modern. Dipadukan dengan warna yang dihasilkan dari ampas kopi membuat warna pakaiannya lebih menarik dan beda dari produk fashion pada umumnya.

Pesan yang ingin disampaikan melalui peracangan ini adalah produk fashion pewarna alami dari ampas kopi merupakan produk fashion yang bagus dan memiliki keunikan tersendiri dari pada produk fashion dengan pewarna tekstil, sehingga produk ini memerlukan publikasi yang dapat memvisualisasikan keunikan dan keindahannya. Tema yang akan dipakai dalam perancangan foto ini adalah menonjolkan keindahan dan keunikan produk fashion pewarna alami dari ampas kopi.

Konsep penyajian dalam perancangan ini adalah mengangkat produk fashion pewarna alami dari ampas kopi melalui fotografi fashion editorial dengan konsep "Nature Fashion Photography". Dengan menggunakan konsep ini, perancang ingin menunjukan kealamian produk fashion ampas kopi ini dan menunjukan keunikannya. Target dalam perancangan ini adalah mereka yang tinggal di Indonesia, rentang usia 20 hingga 30 tahun, berjenis kelamin laki-laki maupun perempuan. Berpendidikan SMA dan S1. Tidak ditujukan untuk agama maupun ras tertentu. Strata ekonomi sosial di level A dan B. Secara psikografis, mereka gemar membeli pakaian dan menyukai fotografi, aktif di media sosial dan selalu update informasi tentang dunia fashion.

Make-up yang digunakan dalam karya ini adalah jenis make-up bold dengan warna yang menyesuaikan dengan produk fashionnya; menggunakan teknik editing program digital yaitu Photoshop. Proses editing diperlukan untuk melakukan komposit terhadap hal-hal yang diperlukan, dan untuk mendapatkan tone warna yang diinginkan maka memerlukan Lightroom. Media sosial akan menjadi media pendukung dalam perancangan ini selain media utama berupa buku elektronik (e-book). $E$-book inilah yang berisi foto-foto hasil karya perancangan dan dapat diakses melalui link di media sosial.

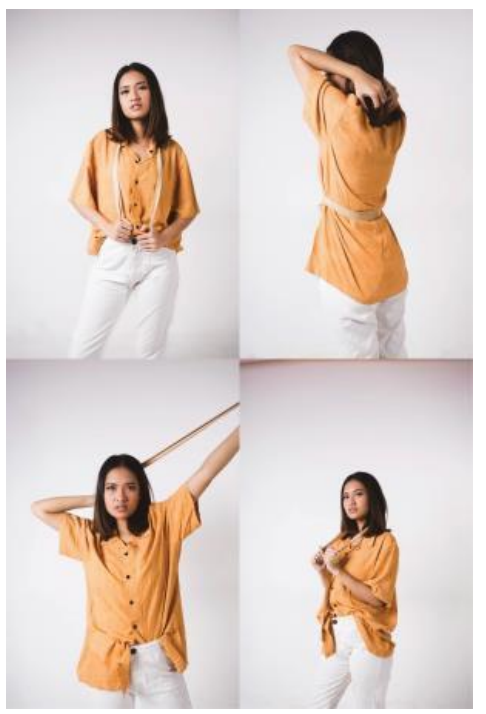

Gambar 1. Hasil foto akhir (1)

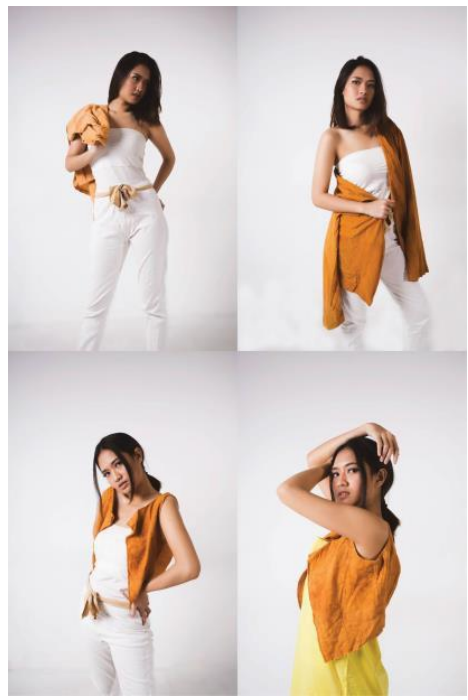

Gambar 2. Hasil foto akhir (2)

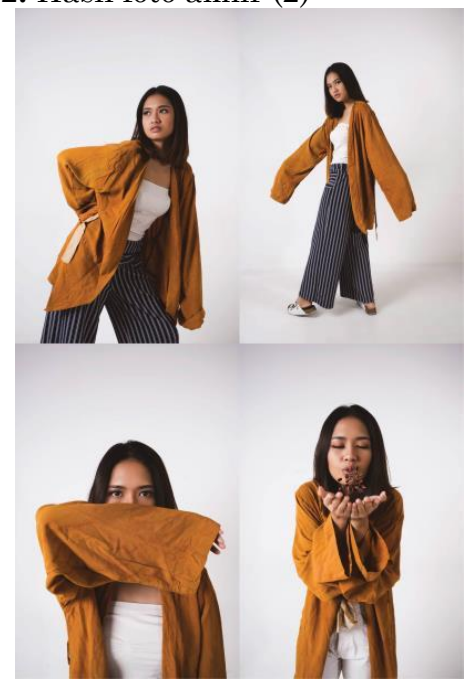

Gambar 3. Hasil foto akhir (3) 


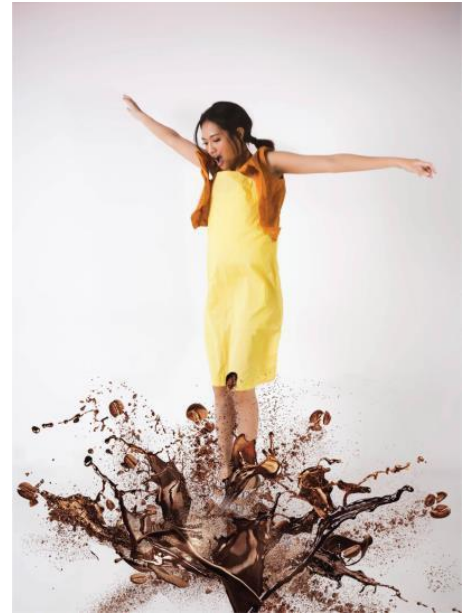

Gambar 4. Hasil foto akhir (4)
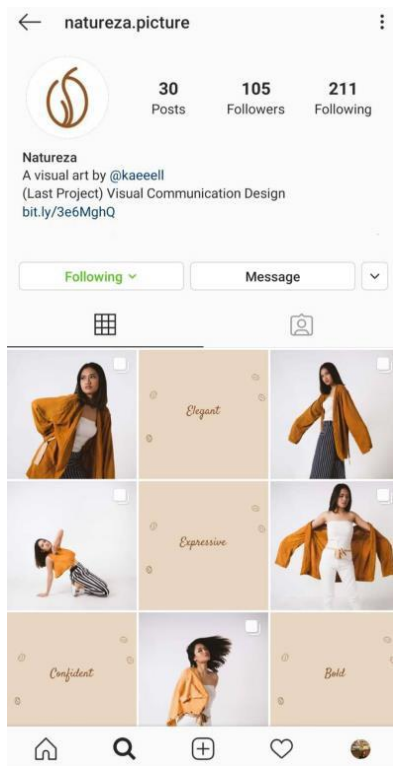

Gambar 5. Feed di Instagram (1)

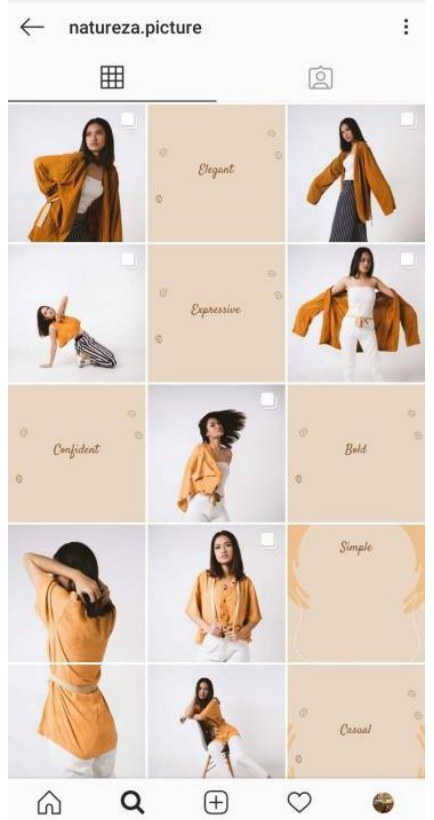

Gambar 6. Feed di Instagram (2)

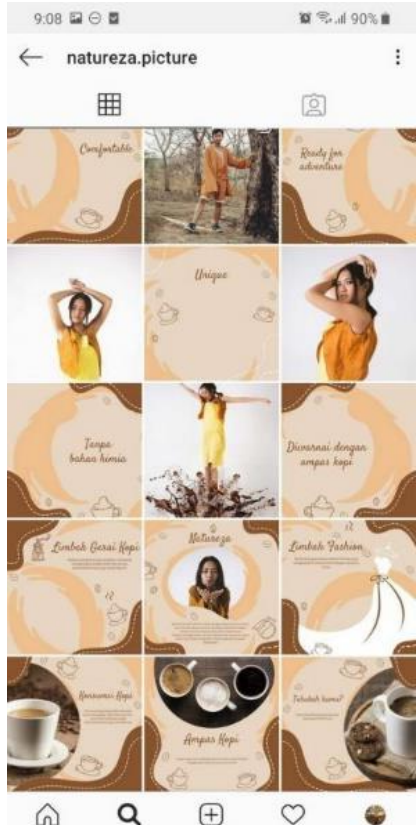

Gambar 7. Feed di Instagram (3)
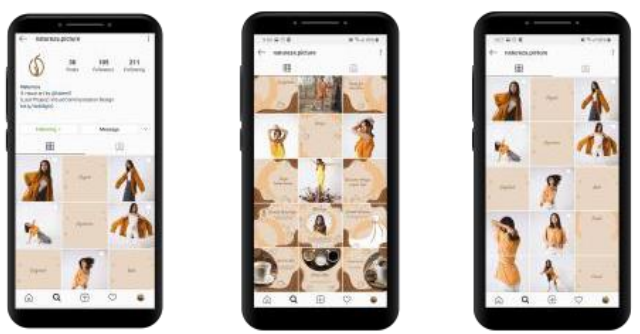

Gambar 8. Desain Instagram

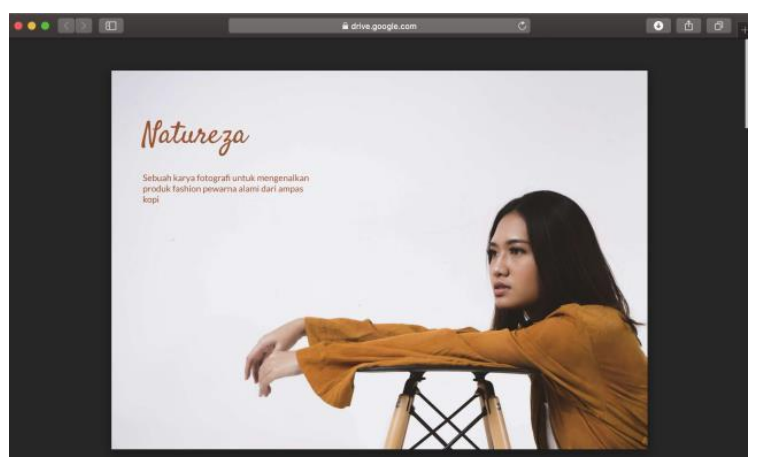

Gambar 9. E-Book

\section{Simpulan}

Pada proses perancangan ini terdapat beberapa kendala yang dialami khususnya pada saat eksekusi pemotretan berlangsung. Hal-hal tidak terduga terjadi secara tiba-tiba. Pandemi corona yang membuat kota Surabaya menjalankan Pembatasan Sosial Berskala Besar (PSBB) membuat sulitnya mencari lokasi untuk melakukan pemotretan. Selain itu banyak model yang menolak untuk melakukan 
photoshoot selama PSBB. Penyedia produk fashion yang pulang ke daerah asalnya di daerah Jawa Tengah membuat eksekusi karya menjadi tertunda.

Dari perancangan karya fotografi ini, kesimpulan yang dapat diambil yaitu produk fashion pewarna alami dari ampas kopi memiliki desain yang bagus seperti produk fashion pada umumnya. Warna yang dihasilkan tidak kalah menarik, dan terkesan unik. Selain itu produk fashion ini nyaman dipakai dalam segala kegiatan baik di indoor maupun outdoor. Para pelaku bisnis fashion perlu memulai untuk membuat banyak produknya yang terbuat dari pewarna alami untuk mengurai limbah yang dihasilkan. Ampas kopi sangat cocok digunakan sebagai pewarna alami dengan mengingat banyaknya konsumsi kopi di Indonesia yang menghasilkan banyak ampas kopi tiap harinya. Perancangan ini mendapatkan respon positif dari masyarakat. Foto instagram mendapatkan like dan respon berupa komentar yang positif. Banyak dari mereka yang baru mengetahui adanya produk fashion dari pewarna alami, dan mereka menyukainya.

\section{Daftar Pustaka}

Bate, D. 2009. Photography: The Key Concepts. Oxford: Oxford International Publisher.

Bull, S. 2010. Photography: Routledge Introductions to Media and Communication. London: Routledge.

Calne, D. B., 2004. Batas Nalar: Rasionalitas dan Perilaku Manusia. Terj. T. Simbolon. Jakarta: Kepustakaan Populer Gramedia.

Enrico. 2018, Dampak Limbah Cair Industri Tekstil Terhadap Lingkungan dan Aplikasi
Tehnik Eco Printing Sebagai Usaha Mengurangi Limbah. Universitas Ciputra, Surabaya.

Gani, R., \& Kusumalestari, R. R. 2013, Jurnalistik Foto: Suatu Pengantar, Simbiosa Rekatama Media, Bandung.

Hamdan, N. 2019, Pengguna Instagram di Indonesia Terbesar ke-4 Dunia, https://www.tagar.id/pengguna-instagramdi-indonesia-terbesar-ke4-dunia

Hauskeller, M. 2015. Seni: Apa Itu?. Terj. Graha dan J. Wizemann. Yogyakarta: Kanisius.

Kaiser, S. B. 2019, Fashion and Cultural Studies, Bloomsbury Visual Arts, London.

Kawamura, S. 1991, Integrated Design of Water Treatment Facilities, John Willey \& Sons Inc, New Jersey.

Mahmud, M. 2019, Pewarna Alami. https://www.scribd.com/document/33665189 6/Pewarna-Alami

Nugroho, R. A. 2006, Kamus Fotografi. Andi Offset, Yogyakarta.

Rouse, E. 1989. Understanding Fashion. New York: John Wiley and Sons.

Samanta, A. K., \& Konar, A. 2011, Dyeing of Textiles With Natural Dyes, University of Calcutta, India. DOI: 10.5772/21341

Sudarma, I. K. 2014. Fotografi. Yogyakarta: Graha Ilmu dan Undiksha Press.

Sudjojo, M. 2010. Tak-Tik Fotografi. Jakarta: Bukune.

Suler, J. 2013. Body Language in Photography. Diakses dari http://truecenterpublishing.com/photopsy/b ody_language.htm

Sumardjo, J. 2000. Filsafat Seni. Bandung: Penerbit ITB.

Wijaya, T. 2011. Foto Jurnalistik dalam Dimensi Utuh. Klaten: CV Sahabat. 